\title{
Effects of DNA and Prostaglandin Synthesis Inhibitors on the Stimulation of Bone Resorption by Epidermal Growth Factor in Fetal Rat Long-Bone Cultures
}

\author{
J. A. Lorenzo, J. Quinton, S. Sousa, and L. G. Raisz \\ Division of Endocrinology and Metabolism, Newington Veterans Administration Medical Center, \\ Newington, Connecticut 06111; and University of Connecticut Health Center, Farmington, Connecticut 06032
}

\begin{abstract}
We examined two inhibitors of DNA synthesis, hydroxyurea (HU) and aphidicholin (APC), and two inhibitors of prostaglandin cyclooxygenase, indomethacin and flufenamic acid, for their effects on the resorptive responses of fetal rat long-bone cultures to epidermal growth factor (EGF) and parathyroid hormone (PTH).
\end{abstract}

As we have previously found, HU decreased unstimulated ${ }^{45} \mathrm{Ca}$ release but had little effect on the resorptive response to PTH. HU also did not block resorption stimulated by EGF. Addition of the cyclooxygenase inhibitor, indomethacin, did not alter the resorptive responses of unstimulated or PTH-treated cultures in either the presence or absence of $\mathrm{HU}$ or the resorptive response of bones cultured with EGF alone. However, indomethacin completely blocked the resorptive response to EGF of bones that were cultured with $\mathrm{HU}$. The effects of indomethacin on EGF-mediated resorption in HU-treated cultures appeared to be related to an inhibition of prostaglandin synthesis since flufenamic acid had similar effects. However, the effects of HU on the resorptive response to EGF may not have resulted solely from its inhibitory action on DNA synthesis since APC, in the absence of cyclooxygenase inhibitors, completely blocked EGFmediated resorption without significantly affecting the response to PTH.

These results demonstrate that the mechanisms regulating PTH- and EGF-mediated resorption in fetal rat long-bone cultures differ, and imply that a component of EGF-mediated resorption in these cultures is dependent on sustained DNA synthesis.

\section{Introduction}

Epidermal growth factor (EGF) ${ }^{1}$ is a single chain polypeptide isolated from mouse submaxillary glands (1) and human urine (2) having multiple biological actions in a variety of tissues (36). In bone, EGF has been shown to bind to specific high affinity

Address correspondence to Dr. Lorenzo, Newington Veterans Administration Medical Center, 555 Willard Ave., Newington, CT 06111.

Received for publication 27 March 1984 and in revised form 4 February 1986 .

1. Abbreviations used in this paper: APC, aphidicholin; bPTH, bovine PTH; DAPI, 4',6'-diaidino-2-phenylindole; DMSO, dimethylsulfoxide; EGF, epidermal growth factor; $\mathrm{HU}$, hydroxyurea; $\mathrm{PGE}_{2}$, prostaglandin $E_{2} ; P T H$, parathyroid hormone; TGF-alpha, transforming growth factor alpha.

The Journal of Clinical Investigation, Inc.

Volume 77, June 1986, 1897-1902 receptors $(7,8)$ to stimulate bone resorption $(7,9,10)$ and to inhibit collagen synthesis (11). The mechanism by which EGF stimulates resorption appears dependent on the culture system used. In newborn mouse calvaria cultures, EGF-stimulated resorption is dependent on prostaglandin synthesis and is inhibited by indomethacin $(7,10)$. In contrast, in fetal rat long-bone cultures, EGF-stimulated resorption is not inhibited by indomethacin and is not associated with with an increase in prostaglandin $E_{2}$ in the culture medium (9). The effects of EGF on cell replication in bone are also variable. In fetal rat long bones (9), fetal rat calvaria (11), a rat osteosarcoma cell line (12), and primary cultures of osteoblastlike cells from perinatal mouse and rat bones $(12,13)$, EGF increases DNA synthesis, while in newborn mouse calvaria (7) and in human osteosarcoma cell lines (8), EGF is not mitogenic.

In the current study we determined the effects that two inhibitors of DNA synthesis, hydroxyurea (HU) and aphidicholin (APC) $(14,15)$, had on the resorptive responses of fetal rat longbone cultures to EGF and compared these with their effects on the resorptive response to parathyroid hormone (PTH).

We have previously shown (16) that $\mathrm{HU}(1 \mathrm{mM})$ markedly decreased DNA synthesis in osteoclast progenitors (the population of cells in the cultures which replicate, terminally differentiate, and fuse into multinucliated osteoclasts), but that HU does not prevent PTH from stimulating resorption or forming new osteoclasts in fetal rat long-bone cultures.

\section{Methods}

Culture technique. Bone organ cultures were performed as previously described (16-19). 19-d-old fetal rat forelimb bones labeled in utero with ${ }^{45} \mathrm{Ca}$ were dissected free of surrounding muscle, cartilage, and fibrous tissue. Bones were cultured in $0.5 \mathrm{ml}$ of BGJ medium (Gibco, Grand Island, NY) that was supplemented with $5 \%$ fetal bovine serum (HyClone, Logan, UT). All serum had previously been heated to $57^{\circ} \mathrm{C}$ for $3 \mathrm{~h}$ and treated with dextran-coated charcoal to remove endogenous stimulators of resorption (16). Cultures were incubated with $95 \%$ air, $5 \% \mathrm{CO}_{2}$ at $37^{\circ} \mathrm{C}$. We used a $24-\mathrm{h}$ preculture in medium to remove readily exchangeable ${ }^{45} \mathrm{Ca}$ and then cultured the bones in experimental medium for $120 \mathrm{~h}$. Bones that were treated with either cyclooxygenase or DNA synthesis inhibitors had these agents added first to the preculture medium. Cultures were transferred to fresh experimental medium after $48 \mathrm{~h}$. Experiments that only examined bone resorption were terminated by placing the bones in $0.2 \mathrm{ml}$ of $5 \%$ trichloroacetic acid (TCA) for $1 \mathrm{~h}$. Aliquots $(0.1 \mathrm{ml})$ of medium and the TCA extract of the bones were counted for ${ }^{45} \mathrm{Ca}$ by liquid scintillation in ACS scintillation fluid (Amersham Corp., Arlington Heights, IL). Bone resorption was assessed as the percentage of total ${ }^{45} \mathrm{Ca}$ that was released into the medium.

DNA synthesis. DNA synthesis was assessed as the rate that $\left[{ }^{3} \mathrm{H}\right]$ thymidine was incorporated into the cold acid-insoluble fraction of the bones using previously described techniques $(11,16) .2 \mathrm{~h}$ before the end of an experiment, $1 \mu \mathrm{Ci}$ [methyl- ${ }^{3} \mathrm{H}$ ] thymidine (specific activity 20 $\mathrm{Ci} / \mathrm{mM}$; New England Nuclear, Boston, MA) was added to each culture. In these experiments no additional cold thymidine was added to the 
medium. Experiments were terminated by washing the bones in saline, blotting them on filter paper, and placing them in a counting vial with $0.2 \mathrm{ml}$ of $5 \% \mathrm{TCA}$ at $4^{\circ} \mathrm{C}$. After $1 \mathrm{~h}$, the TCA was removed to another vial and the bones were washed with a second $0.2 \mathrm{ml}$ of cold TCA. Both TCA samples were then pooled and the bones were rinsed with $1 \mathrm{ml}$ of $70 \%$ ethanol, air dried, and dissolved in $0.4 \mathrm{ml}$ of NCS tissue solubilizer (Amersham Corp.) at room temperature for at least $8 \mathrm{~h}$. The medium, TCA extract, and the NCS digest were counted by liquid scintillation in ACS scintillation fluid (Amersham Corp.) for ${ }^{3} \mathrm{H}$ and ${ }^{45} \mathrm{Ca}$. Total $\left[{ }^{3} \mathrm{H}\right]$ thymidine counts were normalized for variations in bone size by dividing by the total ${ }^{45} \mathrm{Ca}$ counts. Experiments used bones from a single litter or, at most, equal numbers of bones from two litters to further minimize bone size variability.

DNA content. The DNA content of the bones was measured according to the method of Brunk et al. (20). In these experiments, bones were cultured in groups of four per culture well. At the conclusion of an experiment bones were blotted dry, washed in saline, and extracted in $0.2 \mathrm{ml}$ of $5 \%$ TCA for $1 \mathrm{~h}$ at $4^{\circ} \mathrm{C}$. Bones were then transferred to $0.5 \mathrm{ml}$ of $0.5 \mathrm{~N} \mathrm{NaOH}$ for $72 \mathrm{~h}$ at room temperature and solubilized on ice using a cell sonicator. Aliquots $(0.1 \mathrm{ml})$ of the solubilized bones were neutralized with $0.1 \mathrm{ml}$ of $0.5 \mathrm{M}$ acetic acid and reacted with $2 \mathrm{ml}$ of 4',6'-diaidino-2-phenylindole (DAPI) $(100 \mathrm{ng} / \mathrm{ml})$ in a buffer composed of $100 \mathrm{mM} \mathrm{NaCl}, 10 \mathrm{mM}$ EDTA, and $10 \mathrm{mM}$ Tris, $\mathrm{pH}$ 7.0. A standard curve was constructed using calf thymus DNA in identical solutions. Standards and samples were run in duplicate. Fluorescence of the DAPI was detected at $450 \mathrm{nM}$ using an excitation beam of $360 \mathrm{nM}$ in a fluorescence spectrophotometer (Perkin-Elmer Corp., Norwalk, CT).

Reagents. Purified human and mouse EGF were a gift from Dr. Harry Gregory of Imperial Chemical Industries, Macclesfield Chesire, England. Purified mouse EGF was purchased from Biomedical Technologies Inc., Cambridge, MA. Synthetic bovine parathyroid hormone 1-34 was purchased from Boehringer Mannheim Corp., Indianapolis, IN. All other reagents were from Sigma Chemical Co., St Louis, MO. Stock solutions of EGF and PTH were in $0.001 \mathrm{~N} \mathrm{HCl}$ containing $0.1 \%$ bovine serum albumin. Stock solutions of indomethacin $(10 \mathrm{mM})$ and flufenamic acid $(10 \mathrm{mM})$ were in absolute ethanol. Stock aphidicholin $(10 \mathrm{mM})$ was dissolved in dimethylsulfoxide (DMSO). All stock solutions were diluted 1:1,000 or greater in medium. In experiments using indomethacin, flufenamic acid, or aphidicolin, equivalent concentrations of ethanol or DMSO were added to all groups.

Statistics. Differences were analyzed by the two tailed Student's $t$ test.

\section{Results}

The responses of the bones to all three preparations of EGF were essentially identical and results have been pooled. EGF stimulated bone resorption at $30 \mathrm{ng} / \mathrm{ml}$ after both 48 and $120 \mathrm{~h}$ (treated/control ratios $1.53 \pm 0.12$ and $1.57 \pm 0.11$, respectively) (Table I). Lower concentrations had no significant stimulatory effect on resorption, although after $120 \mathrm{~h}, 1 \mathrm{ng} / \mathrm{ml}$ was slightly inhibitory.

As we have previously found, cultures treated with $1 \mathrm{mM}$ $\mathrm{HU}$ alone released significantly less ${ }^{45} \mathrm{Ca}$ than did controls. Addition of EGF to HU-treated cultures stimulated resorption in a dose-dependent manner after $120 \mathrm{~h}$. Although absolute amounts of ${ }^{45} \mathrm{Ca}$ released from bones treated with $\mathrm{HU}$ and EGF were less than from cultures treated with EGF alone, treated/ control ratios for EGF treated bones were greater and more significant when HU was present because of the decrease in unstimulated resorption. HU treatment did not inhibit cell-mediated resorption completely, since devitalized bones released less ${ }^{45} \mathrm{Ca}$ than did live bones treated with $\mathrm{HU}$ (Table II). In addition, neither EGF nor PTH altered the release of ${ }^{45} \mathrm{Ca}$ from devitalized bone (data not shown).
Table I. Effect of EGF on ${ }^{45}$ Ca Release from Fetal Rat Long Bones Cultured in the Presence and Absence of Hydroxyurea

\begin{tabular}{lll}
\hline & \multicolumn{2}{l}{${ }^{45}$ Ca percent release } \\
\cline { 2 - 3 } Group & 48 Hour & 120 Hour \\
\hline Control & $17 \pm 1$ & $47 \pm 4$ \\
$\quad+$ EGF $(30 \mathrm{ng} / \mathrm{ml})$ & $26 \pm 2^{*}$ & $74 \pm 5^{*}$ \\
+ EGF $(10 \mathrm{ng} / \mathrm{ml})$ & $21 \pm 1$ & $52 \pm 5$ \\
+ EGF $(3 \mathrm{ng} / \mathrm{ml})$ & $20 \pm 1$ & $54 \pm 6$ \\
+ EGF $(1 \mathrm{ng} / \mathrm{ml})$ & $16 \pm 1$ & $34 \pm 3 \ddagger$ \\
HU $(1 \mathrm{mM})$ & $12 \pm 1 \S$ & $17 \pm 1 \S$ \\
+ EGF $(30 \mathrm{ng} / \mathrm{ml})$ & $19 \pm 2 \ddagger$ & $45 \pm 6^{*}$ \\
+ EGF $(10 \mathrm{ng} / \mathrm{ml})$ & $15 \pm 1$ & $41 \pm 6^{*}$ \\
+ EGF $(3 \mathrm{ng} / \mathrm{ml})$ & $13 \pm 1$ & $29 \pm 4^{*}$ \\
+ EGF $(1 \mathrm{ng} / \mathrm{ml})$ & $13 \pm 1$ & $22 \pm 2$ \\
\end{tabular}

Values are mean \pm SEM for 22 bones per group cultured for $120 \mathrm{~h}$.

* Significant effect of EGF, $P<0.01$.

$\ddagger$ Significant effect of EGF, $P<0.05$.

$\S$ Significant effect of $\mathrm{HU}, P<0.01$.

EGF increased DNA synthesis, which was measured as the incorporation of $\left[{ }^{3} \mathrm{H}\right]$ thymidine into the cold acid-insoluble fraction of the bones (Table III) $(11,16)$. EGF also caused a smaller, more variable, increase in $\left[{ }^{3} \mathrm{H}\right]$ thymidine counts in the cold acid-extractable fraction of the bones, a measure of thymidine transport into cells, which was significant for the 30 - and $3-\mathrm{ng} / \mathrm{ml}$ groups. The effects of EGF on $\left[{ }^{3} \mathrm{H}\right]$ thymidine incorporation into the bones occurred at concentrations that were lower than those necessary to stimulate resorption. HU (1 mM) inhibited $\left[{ }^{3} \mathrm{H}\right]$ thymidine incorporation into the cold acid-insoluble fraction of all groups by $>90 \%$ without affecting $\left[{ }^{3} \mathrm{H}\right]$ thymidine in the cold acid extracts.

The increase in $\left[{ }^{3} \mathrm{H}\right]$ thymidine counts in the cold acid-extractable fraction of bones treated with EGF implied that EGF stimulated $\left[{ }^{3} \mathrm{H}\right]$ thymidine transport into bone cells. This effect of EGF could have increased the specific activity of the intracellular pool of thymidine available for incorporation into DNA and falsely increased $\left[{ }^{3} \mathrm{H}\right]$ thymidine counts in the cold acidinsoluble fraction. To better document whether fetal rat longbone cultures do respond mitogenically to EGF and to monitor the cytotoxicity of HU on the cultures we measured the DNA content of the bones at various times (Table IV). We found that

Table II. Effect of Hydroxyurea on ${ }^{45} \mathrm{Ca}$ Release from Live and Devitalized Fetal Rat Long-bone Cultures

\begin{tabular}{lll}
\hline & \multicolumn{2}{l}{${ }^{45} \mathrm{Ca}$ percent release } \\
\cline { 2 - 3 } Group & Live & Devitalized \\
\hline Control & $48.0 \pm 10.4$ & $14.4 \pm 0.7 \ddagger$ \\
HU $(1 \mathrm{mM})$ & $17.0 \pm 0.5^{*}$ & $14.0 \pm 0.4 \ddagger$
\end{tabular}

Values are mean \pm SE for six bones per group cultured for $120 \mathrm{~h}$. Bones were devitalized by three cycles of freezing $\left(-70^{\circ} \mathrm{C}\right)$ and thawing.

* Significant effect of HU, $P<0.01$.

$¥$ Significant effect of devitalization, $P<0.01$. 
Table III. Effect of EGF on $\left[{ }^{3} H\right]$ Thymidine Incorporation into Fetal Rat Long Bones Cultured in the Presence and Absence of Hydroxyurea

\begin{tabular}{|c|c|c|}
\hline \multirow[b]{2}{*}{ Group } & \multicolumn{2}{|c|}{${ }^{3} \mathrm{H} \mathrm{cpm} \times 10^{-2}$ per total ${ }^{45} \mathrm{Ca} \mathrm{cpm}$} \\
\hline & $\begin{array}{l}\text { Cold acid- } \\
\text { extractable } \\
{ }^{3} \mathrm{H} \text { fraction }\end{array}$ & $\begin{array}{l}\text { Cold acid- } \\
\text { insoluble } \\
{ }^{3} \mathrm{H} \text { fraction }\end{array}$ \\
\hline Control & $65.4 \pm 5.8$ & $40.5 \pm 4.5$ \\
\hline$+\mathrm{EGF}(30 \mathrm{ng} / \mathrm{ml})$ & $97.2 \pm 6.3^{*}$ & $128.0 \pm 24.8^{*}$ \\
\hline$+\mathrm{EGF}(10 \mathrm{ng} / \mathrm{ml})$ & $83.8 \pm 8.2$ & $101.2 \pm 15.3^{*}$ \\
\hline$+\mathrm{EGF}(3 \mathrm{ng} / \mathrm{ml})$ & $100.3 \pm 6.7^{*}$ & $86.9 \pm 9.6^{*}$ \\
\hline$+\mathrm{EGF}(1 \mathrm{ng} / \mathrm{ml})$ & $87.3 \pm 11.0$ & $73.8 \pm 11.9 \ddagger$ \\
\hline HU (1 mM) & $61.3 \pm 6.7$ & $1.2 \pm 0.2 \S$ \\
\hline+ EGF $(30 \mathrm{ng} / \mathrm{ml})$ & $61.7 \pm 5.6$ & $1.0 \pm 0.2 \S$ \\
\hline + EGF (10 ng/ml) & $54.2 \pm 5.0$ & $0.8 \pm 0.2 \S$ \\
\hline$+\mathrm{EGF}(3 \mathrm{ng} / \mathrm{ml})$ & $60.1 \pm 4.4$ & $1.0 \pm 0.1 \S$ \\
\hline$+\mathrm{EGF}(1 \mathrm{ng} / \mathrm{ml})$ & $57.3 \pm 7.4$ & $1.0 \pm 0.2 \S$ \\
\hline
\end{tabular}

Values are mean \pm SEM for 14 bones per group cultured for $120 \mathrm{~h}$.

* Significant effect of EGF, $P<0.01$.

‡ Significant effect of EGF, $P<0.05$.

$\S$ Significant effect of $\mathrm{HU}, P<0.01$.

the DNA content of the cultures decreased in all groups. In controls, changes in DNA content were minimal after the preculture period and declined thereafter. In groups treated with EGF, DNA content declined less rapidly than in controls and was significantly greater than control after $120 \mathrm{~h}$. In groups treated with HU alone, DNA content was significantly below control after $48 \mathrm{~h}$ of culture but equal to control after $120 \mathrm{~h}$. In groups treated with HU plus EGF, DNA content declined more rapidly than in controls or groups treated with $\mathrm{HU}$ alone and was significantly below either after $120 \mathrm{~h}$.

Indomethacin $(1 \mu \mathrm{M})$ alone, an inhibitor of prostaglandin cyclooxygenase (21), did not alter the resorptive response to either EGF or PTH (Table V), and its effects on the incorporation of $\left[{ }^{3} \mathrm{H}\right]$ thymidine into the bones was limited to blocking the inhibitory actions of PTH on ${ }^{3} \mathrm{H}$-counts in the cold acid-extractable fraction. When $\mathrm{HU}$ was present in the medium, $1 \mu \mathrm{M}$ indomethacin inhibited unstimulated resorption to a small degree.

Table IV. Effect of EGF on the DNA Content of Fetal Rat Long Bones Cultured in the Presence and Absence of Hydroxyurea

\begin{tabular}{|c|c|c|c|c|}
\hline \multirow[b]{2}{*}{ Group } & \multirow{2}{*}{$\begin{array}{l}\text { At the } \\
\text { time of } \\
\text { removal } \\
\text { of bones } \\
\text { from the } \\
\text { fetuses }\end{array}$} & \multirow[b]{2}{*}{$\begin{array}{l}\text { After } 24 \mathrm{~h} \\
\text { preculture }\end{array}$} & \multicolumn{2}{|c|}{$\begin{array}{l}\text { DNA content (micrograms per } \\
\text { four bones) }\end{array}$} \\
\hline & & & $\begin{array}{l}\text { After } 48 \mathrm{~h} \text { of } \\
\text { experimental } \\
\text { culture }\end{array}$ & $\begin{array}{l}\text { After } 120 \mathrm{~h} \text { of } \\
\text { experimental } \\
\text { culture }\end{array}$ \\
\hline Control & $5.3 \pm 0.3$ & $5.2 \pm 0.4$ & $3.8 \pm 0.3$ & $1.9 \pm 0.2$ \\
\hline EGF (30 ng/ml) & & & $4.4 \pm 0.3$ & $3.6 \pm 0.5^{*}$ \\
\hline HU (1 mM) & & $4.1 \pm 0.3$ & $3.2 \pm 0.1 \ddagger$ & $1.9 \pm 0.2$ \\
\hline $\mathrm{HU}+\mathrm{EGF}$ & & & $2.8 \pm 0.3 \ddagger$ & $1.3 \pm 0.1 \ddagger \S$ \\
\hline
\end{tabular}

Values are mean \pm SEM for 4-11 determinations per group.

* Significantly different from control, $P<0.01$.

¥ Significantly different from control, $P<0.05$.

$\S$ Significantly different from $\mathrm{HU}$ alone, $P<0.05$.
Table V. Effect of EGF, Bovine Parathyroid Hormone (bPTH), and Indomethacin on ${ }^{45} \mathrm{Ca}$ Release and $\left[{ }^{3} \mathrm{H}\right]$ Thymidine Incorporation in Fetal Long Bones Cultured in the Presence and Absence of Hydroxyurea

\begin{tabular}{|c|c|c|c|}
\hline \multirow[b]{2}{*}{ Group } & \multirow[b]{2}{*}{$\begin{array}{l}{ }^{45} \mathrm{Ca} \\
\text { Percent } \\
\text { release }\end{array}$} & \multicolumn{2}{|c|}{${ }^{3} \mathrm{H} \mathrm{cpm} \times 10^{-2}$ per total ${ }^{45} \mathrm{Ca} \mathrm{cpm}$} \\
\hline & & $\begin{array}{l}\text { Cold acid- } \\
\text { extractable } \\
{ }^{3} \mathrm{H} \text { fraction }\end{array}$ & $\begin{array}{l}\text { Cold acid- } \\
\text { insoluble } \\
{ }^{3} \mathrm{H} \text { fraction }\end{array}$ \\
\hline Control & $24 \pm 2$ & $29.2 \pm 2.7$ & $36.1 \pm 2.2$ \\
\hline$+\mathrm{EGF}(30 \mathrm{ng} / \mathrm{ml})$ & $58 \pm 6^{*}$ & $38.3 \pm 4.6$ & $131.3 \pm 26.1^{*}$ \\
\hline \multicolumn{4}{|l|}{ bPTH $(1-34)$} \\
\hline$(100 \mathrm{ng} / \mathrm{ml})$ & $92 \pm 5 \ddagger$ & $20.3 \pm 1.7 \S$ & $11.9 \pm 1.6 \ddagger$ \\
\hline Indomethacin $(1 \mu \mathrm{M})$ & $24 \pm 2$ & $28.3 \pm 2.1$ & $33.6 \pm 3.9$ \\
\hline+ EGF & $49 \pm 6^{*}$ & $40.5 \pm 3.9^{11}$ & $128.9 \pm 18.7^{*}$ \\
\hline bPTH & $96 \pm 2 \ddagger$ & $25.6 \pm 2.0$ & $14.7 \pm 2.0 \ddagger$ \\
\hline $\mathrm{HU}(1 \mathrm{mM})$ & $22 \pm 2$ & $22.6 \pm 1.6$ & $0.5 \pm 0.1 \pi$ \\
\hline$+\mathrm{EGF}$ & $42 \pm 5^{*}$ & $25.1 \pm 2.2$ & $0.5 \pm 0.1 \pi$ \\
\hline bPTH & $90 \pm 3 \ddagger$ & $18.4 \pm 0.8 \S$ & $0.3 \pm 0.1 \pi$ \\
\hline $\mathrm{HU}+$ indomethacin & $17 \pm 1^{* *}$ & $25.9 \pm 3.2$ & $0.3 \pm 0.1 \pi$ \\
\hline$+\mathrm{EGF}$ & $20 \pm 2$ & $27.8 \pm 5.1$ & $0.3 \pm 0.1 \uparrow$ \\
\hline bPTH & $94 \pm 2 \ddagger$ & $27.3 \pm 3.3$ & $0.1 \pm 0.1 \pi$ \\
\hline
\end{tabular}

Values are mean \pm SE for 5-40 determinations per group cultured for $120 \mathrm{~h}$.

* Significant effect of EGF, $P<0.01$

¥ Significant effect of bPTH, $P<0.01$.

$\S$ Significant effect of bPTH, $P<0.05$.

"Significant effect of EGF, $P<0.05$.

I Significant effect of $\mathrm{HU}, P<0.01$.

** Significant effect of $\mathrm{HU}+$ indomethacin, $P<0.05$.

This effect was significant in one set of experiments (Table V) but not in another (Table VI). In contrast to its effects on EGFmediated resorption in the absence of $\mathrm{HU}$, indomethacin, in the presence of $\mathrm{HU}$, blocked the resorptive response to EGF but had little effect on the response to PTH either at $100 \mathrm{ng} / \mathrm{ml}$, a

Table VI. Effect of Hydroxyurea and Indomethacin on ${ }^{45} \mathrm{Ca}$ Release in Fetal Rat Long-bone Cultures Treated with bPTH

\begin{tabular}{cl}
\hline & ${ }^{45} \mathrm{Ca}$ Percent release \\
\hline Control & $41 \pm 3$ \\
+ bPTH $(1-34)(1 \mathrm{ng} / \mathrm{ml})$ & $53 \pm 4^{*}$ \\
Indomethacin $(1 \mu \mathrm{M})$ & $42 \pm 5.0$ \\
+ bPTH $(1 \mathrm{ng} / \mathrm{ml})$ & $56 \pm 6$ \\
HU (1 mM) & $31 \pm 3 \ddagger$ \\
+ bPTH & $63 \pm 5 \S$ \\
HU + indomethacin $(1 \mu \mathrm{M})$ & $27 \pm 3^{\| \prime}$ \\
+ bPTH & $50 \pm 5 \S$ \\
\hline
\end{tabular}

Values are mean \pm SEM for 12-18 bones per group cultured for $120 \mathrm{~h}$. * Significant effect of PTH, $P<0.05$.

¥ Significant effect of HU, $P<0.01$.

$\S$ Significant effect of PTH, $P<0.01$.

"Significant effect of $\mathrm{HU}, P<0.05$. 
concentration which produced a maximal resorptive response (Table $\mathrm{V}$ ), or $1 \mathrm{ng} / \mathrm{ml}$, a concentration which produced a resorptive response similar in magnitude to that of $30 \mathrm{ng} / \mathrm{ml} \mathrm{EGF}$ (Table VI). Because HU inhibited the resorption in unstimulated cultures, the magnitude of the resorptive response to $1 \mathrm{ng} / \mathrm{ml}$ PTH, measured as a treated over control ratio, was significantly greater in bones treated with HU or HU plus indomethacin than in controls. We have also found that medium containing $1 \mathrm{mM}$ $\mathrm{HU}, 1 \mu \mathrm{M}$ indomethacin, and $30 \mathrm{ng} / \mathrm{ml}$ EGF did not block the resorptive response of the cultures to PTH (data not shown).

In the presence of $\mathrm{HU}$, indomethacin again blocked the inhibitory effects of PTH on ${ }^{3} \mathrm{H}$-counts in the cold acid-extractable fraction (Table V). The effects of indomethacin on EGF-mediated resorption in HU-treated cultures appeared to be related to the inhibition of prostaglandin synthesis since flufenamic acid, an unrelated inhibitor of prostaglandin cyclooxygenase (21), also inhibited the resorptive response of the cultures to EGF when HU was present in the medium but had little effect on the response to PTH (Table VII).

To further determine the relationship between DNA synthesis and EGF-mediated resorption, we examined the effects of aphidicolin, an inhibitor of DNA synthesis that is unrelated to $\mathrm{HU}$ in either its structure or mechanism of action (15). As with $\mathrm{HU}$, APC $(10 \mathrm{ng} / \mathrm{ml})$ decreased $\left[{ }^{3} \mathrm{H}\right]$ thymidine incorporation into the cold acid-insoluble fraction of the bones by $>90 \%$ (Table VIII). However, APC also decreased the incorporation of $\left[{ }^{3} \mathrm{H}\right]$ thymidine into the cold acid-extractable fraction by $25-$ $50 \%$ and hence, its inhibitory effect on DNA synthesis may not have been as great as those of HU. The effects of APC on resorption were also different from those of HU. In the absence of prostaglandin cyclooxygenase inhibitors, APC decreased unstimulated resorption, completely blocked the resorptive response to EGF, but did not significantly affect resorption stimulated by PTH.

\section{Discussion}

These experiments again demonstrate that both EGF and PTH stimulate bone resorption in fetal rat long-bone cultures through

Table VII. Effects of EGF, bPTH, and Flufenamic Acid (FLU) on ${ }^{45} \mathrm{Ca}$ Release in Fetal Rat Long Bones Cultured in the Presence and Absence of Hydroxyurea

\begin{tabular}{ll}
\hline Group & ${ }^{45} \mathrm{Ca}$ Percent release \\
\hline Control & $40 \pm 4$ \\
+ EGF $(30 \mathrm{ng} / \mathrm{ml})$ & $67 \pm 6^{*}$ \\
+ bPTH $(1-34)(100 \mathrm{ng} / \mathrm{ml})$ & $99 \pm 1 \ddagger$ \\
HU $(1 \mathrm{mM})$ & $20 \pm 1 \S$ \\
+ EGF & $41 \pm 6^{*}$ \\
+ bPTH & $87 \pm 9 \ddagger$ \\
HU + FLU $(10 \mu \mathrm{M})$ & $24 \pm 3 \S$ \\
+ EGF & $24 \pm 2$ \\
+ bPTH & $91 \pm 3 \ddagger$
\end{tabular}

Values are mean $\pm \mathrm{SE}$ for 10 determinations per group cultured for $120 \mathrm{~h}$.

* Significant effect of EGF, $P<0.01$.

¥ Significant effect of PTH, $P<0.01$

$\S$ Significant effect of $\mathrm{HU}, P<0.01$.
Table VIII. Effects of EGF and bPTH on ${ }^{45} \mathrm{Ca}$ Release and $\left[{ }^{3} \mathrm{H}\right]$ Thymidine Incorporation in Fetal Rat Long Bones Cultured in the Presence and Absence of APC

\begin{tabular}{|c|c|c|c|}
\hline \multirow[b]{2}{*}{ Group } & \multirow[b]{2}{*}{$\begin{array}{l}{ }^{45} \mathrm{Ca} \\
\text { Percent } \\
\text { release }\end{array}$} & \multicolumn{2}{|c|}{${ }^{3} \mathrm{H} \mathrm{cpm} \times 10^{-2}$ per total ${ }^{45} \mathrm{Ca} \mathrm{cpm}$} \\
\hline & & $\begin{array}{l}\text { Cold acid- } \\
\text { extractable } \\
{ }^{3} \mathrm{H} \text { fraction }\end{array}$ & $\begin{array}{l}\text { Cold acid- } \\
\text { insoluble } \\
{ }^{3} \mathrm{H} \text { fraction }\end{array}$ \\
\hline Control & $47 \pm 6$ & $107.1 \pm 7.3$ & $123.7 \pm 11.2$ \\
\hline$+\mathrm{EGF}(30 \mathrm{ng} / \mathrm{ml})$ & $72 \pm 4^{*}$ & $205.6 \pm 15.7^{*}$ & $718.7 \pm 163.8^{*}$ \\
\hline \multicolumn{4}{|l|}{ + bPTH (1-34) } \\
\hline$(100 \mathrm{ng} / \mathrm{ml})$ & $99 \pm 1 \ddagger$ & $90.5 \pm 8.1$ & $80.5 \pm 12.6 \S$ \\
\hline $\operatorname{APC}(10 \mathrm{ng} / \mathrm{ml})$ & $14 \pm 1^{11}$ & $78.0 \pm 4.5^{\prime \prime}$ & $2.3 \pm 0.3^{\prime \prime}$ \\
\hline+ EGF & $14 \pm 1$ & $54.5 \pm 5.2^{11}$ & $1.2 \pm 0.2^{\prime \prime}$ \\
\hline + bPTH & $93 \pm 3 \ddagger$ & $79.8 \pm 8.1 \pi$ & $3.6 \pm 0.9^{\prime \prime}$ \\
\hline
\end{tabular}

Values are mean $\pm \mathrm{SE}$ for five determinations per group cultured for $120 \mathrm{~h}$.

* Significant effect of EGF, $P<0.01$.

‡ Significant effect of PTH, $P<0.01$.

$\S$ Significant effect of PTH, $P<0.05$.

"Significant effect of APC, $P<0.01$.

I Significant effect of APC, $P<0.05$.

mechanisms that are not inhibitable by indomethacin. However, the response to EGF was more variable than to PTH, and small effects of indomethacin on EGF-mediated resorption could have been missed. In contrast to our previous results, we also found that EGF at $1 \mathrm{ng} / \mathrm{ml}$ had a small inhibitory effect on resorption. We are unsure why this inhibitory effect was present in the current experiments and not previously but suspect that small changes in the culture conditions, such as the inclusion of serum, may be responsible.

In contrast to the response of the cultures to EGF alone, resorption stimulated by EGF in HU-treated bones was inhibited by both indomethacin and flufenamic acid. The inhibitory effects of these agents on EGF-mediated resorption appeared to be mediated by their actions on prostaglandin synthesis and not by nonspecific mechanisms, since neither cyclooxygenase inhibitor had more than small inhibitory actions on the resorptive response to PTH. These results imply that, in the presence of HU, resorption stimulated by EGF was dependent on prostaglandin synthesis. However, the mechanism by which HU altered the response of the cultures to EGF may not have resulted solely from its inhibitory actions on DNA synthesis, since APC, which had similar effects on DNA, blocked EGF- but not PTH-mediated resorption in the absence of cyclooxygenase inhibitors.

The effects of EGF on cell replication in these cultures are difficult to interpret because of their heterogeneous cell populations and because their DNA content, and therefore their cell number, declined with time in all groups. The accelerated decline in DNA content that occurred in HU-treated cultures during the first $48 \mathrm{~h}$ of the experimental period did not seem to affect the function of those bone-resorbing cells, which respond to PTH, since inhibitors of DNA synthesis had little effect on the absolute rate of PTH-mediated resorption. Moreover, we have previously found that HU did not affect the number of osteoclasts that were present in either control or PTH-treated cultures (16). Treatment of the cultures with EGF enhanced the rate that $\left[{ }^{3} \mathrm{H}\right]$ thymidine was incorporated into DNA and decreased the rate that DNA content declined. Hence, it appears that EGF acted to either 
stimulate DNA synthesis in a subpopulation of cells or prevent the decrease in cell number that occurred in control cultures. The effects of EGF on $\left[{ }^{3} \mathrm{H}\right]$ thymidine counts in the cold acidextractable fraction of the bones might also be explained by the higher cell numbers in EGF-treated cultures, since additional cells would increase this value even if DNA transport per cell were not altered.

These results imply that the major resorptive effects of PTH on fetal rat long bone cultures are independent of the state of cell replication, but that the response to EGF is not, and therefore that the mechanisms regulating the resorptive effects of EGF differ from those of PTH. Since both HU in the presence of cyclooxygenase inhibitors and aphidicolin alone specifically blocked resorption stimulated by EGF, it appears that continued cell replication is necessary for at least one component of the EGF-mediated resorptive response of fetal rat long-bone cultures. Similarly, the rate that ${ }^{45} \mathrm{Ca}$ is released from unstimulated cultures also appears to be dependent to some degree on continued DNA synthesis, since both HU and APC inhibited this value.

The mechanism by which $\mathrm{HU}$ altered the resorptive response to EGF from one that was independent of prostaglandin synthesis to one that was inhibitable by either indomethacin or flufenamic acid is unknown. HU has been shown to induce both the in vitro and in vivo differentiation of erythroblastic cells (22-24). Therefore, HU could have caused a subpopulation of cells in the fetal rat long-bone cultures to differentiate into a phenotype which was similar to that of cells in newborn mouse calvaria which respond to EGF with enhanced prostaglandin production.

Matsuda et al. (25) have found that HU can alter the intracellular processing of the EGF receptor complex. Since processing of the EGF receptor complex may be important for producing biologic responses to EGF (26), alterations in this process could also be involved in the effects we observed.

Finally, increased prostaglandin production can be seen after cell injury (27). Since cultures treated with HU and EGF had the highest rates of decline in DNA content, the resorptive response to EGF of HU-treated cultures could have been influenced by prostaglandins that were synthesized in response to the higher rates of cell injury and death which occurred in this group.

Recently, the peptide, transforming growth factor alpha (TGF-alpha), which binds and activates the same receptor as EGF, was found to stimulate bone resorption in vitro (28-30). As with EGF, TGF-alpha-mediated resorption is dependent on prostaglandin synthesis in newborn mouse calvaria cultures and independent of prostaglandin synthesis in fetal rat long-bone cultures. TGF-alpha is synthesized and released from a number of neoplasms including the Rice Leydig Cell Tumor, a malignancy which produces humorally mediated hypercalcemia in rats (31). Antibodies to the EGF receptor block the in vitro bone resorbing activity of supernatants derived from cultured Rice Leydig cells (32). Hence, production of TGF-alpha in vivo may be a mechanism regulating the hypercalcemia that is associated with this tumor. Similar TGF-alphalike factors are also produced by human malignancies (33) and, therefore, studies of the mechanisms regulating the resorptive response to EGF in vitro may provide some insight into the mechanisms regulating human malignant hypercalcemia (34).

\section{Acknowledgments}

We wish to thank Miss Carmen D'Alfonso for preparation of this manuscript.
This work was supported by grants AM-31263, AM-18063, and AM07290 from the National Institutes of Health. Dr. Lorenzo is the recipient of a Research Associate Career Development Award from the Veterans Administration.

\section{References}

1. Cohen, S., and J. M. Taylor. 1974. Epidermal growth factor: chemical and biologic characterization. Recent Prog. Horm. Res. 30: 533-550.

2. Gregory, H. 1975. Isolation and structure of urogastrone and its relationship to epidermal growth factor. Nature (Lond.). 257:325-327.

3. Huot, R. I., J. M. Foirdart, R. M. Nardone, and K. Stromberg. 1981. Differential modulation of human chorionic gonadotropin secretion by epidermal growth factor in normal and malignant placental cultures. J. Clin. Endocrinol. Metab. 53:1059-1063.

4. Lee, L., and I. B. Weinstein. 1978. Epidermal growth factor, like phorbol esters, induces plasminogen activator in $\mathrm{He} \mathrm{La}$ cells. Nature (Lond.). 274:696-697.

5. Westermark, K., F. A. Karlsson, and P. Westermark. 1983. Epidermal growth factor modulates thyroid growth and function in culture. Endocrinology. 112:1680-1686.

6. Levine, L., and A. Hassid. 1977. Epidermal growth factor stimulates prostaglandin biosynthesis by canine kidney (MDCK) cells. Biochem. Biophy. Res. Commun. 76:1181-1187.

7. Shupnik, M. A., N. Yuk-Yu Ip, and A. H. Tashjian, Jr. 1980. Characterization and regulation of receptors for epidermal growth factor in mouse calvaria. Endocrinology. 107:1738-1746.

8. Shupnik, M. A., and A. H. Tashjian, Jr. 1982. Epidermal growth factor and phorbol ester actions on human osteosarcoma cells. J. Biol. Chem. 257:12161-12163.

9. Raisz, L. G., H. A. Simmons, A. L. Sandberg, and E. Canalis. 1980. Direct stimulation of bone resorption by epidermal growth factor. Endocrinology. 107:270-273.

10. Tashjian, A. H., Jr., and L. Levine. 1978. Epidermal growth factor stimulates prostaglandin production and bone resorption in cultured mouse calvaria. Biochem. Biophys. Res. Commun. 85:966-975.

11. Canalis, E., and L. Raisz. 1979. Effect of epidermal growth factor on bone formation in vitro. Endocrinology. 104:862-869.

12. Ng, K. W., N. C. Partridge, M. Niall, and T. J. Martin. 1983. Stimulation of DNA synthesis by epidermal growth factor in osteoblastlike cells. Calcif. Tissue Int. 35:624-628.

13. Chen, T. L., C. M. Conc, and D. Feldman. 1983. Gluco-corticoid modulation of cell proliferation in cultured osteoblast-like bone cells: differences between rat and mouse. Endocrinology. 112:1739-1745.

14. Young, C. W., and S. Hodes. 1964. Hydroxyurea: inhibitory effects on DNA metabolism. Science (Wash. DC). 146:1172-1174.

15. Spadari, S., F. Sala, and G. Pedrali-Noy. 1982. Aphidicolin: a specific inhibitor of nuclear DNA replication in eukaryotes. Trend. Bio. Sci. 1:29-32.

16. Lorenzo, J. A., J. M. Hock, and L. G. Raisz. 1983. DNA synthesis is not necessary for osteoclastic responses to parathyroid hormone in cultured fetal rat long bones. J. Clin. Invest. 72:1924-1929.

17. Raisz, L. G. 1965. Bone resorption in tissue culture. Factors influencing the response to parathyroid hormone. J. Clin. Invest. 44: 103-116.

18. Stern, P. H., and L. G. Raisz. 1979. Organ cultures of bone. In Skeletal Research: An Experimental Approach. D. J. Simmons and A. S. Kunin, editors. Academic Press, Inc., New York. 21-59.

19. Raisz, L. G., J. Lorenzo, S. Gworek, B. Kream, and M. Rosenblatt. 1979. Comparison of the effects of a potent synthetic analog of bovine parathyroid hormone with native bPTH-(1-84) and synthetic bPTH(1-34) on bone resorption and collagen synthesis. Calcif. Tissue Int. 29: 215-218.

20. Brunk, C. F., K. C. Jones, and T. W. James. 1979. Assay for nanogram quantities of DNA in cellular homogenates. Anal. Biochem. 92:497-500.

21. Brune, K., K. D. Rainsford, K. Wagner, and B. A. Peskar. 1981. 
Inhibition by anti-inflammatory drugs of prostaglandin production in cultured macrophages. Naunyn-Schmiedeberg's Arch. Pharmacol. 315: 269-276.

22. Charney, P., and T. Maniatis. 1983. Transcriptional regulation of globin gene expression in human erythroid cell line K562. Science (Wash. DC). 220:1281-1283.

23. Letvin, N. L., D. C. Linch, G. P. Beardsley, K. W. McIntyre, and D. G. Nathan. 1984. Augmentation of fetal-hemoglobin production in anemic monkeys by hydroxyurea. $N$. Engl. J. Med. 310:869-874

24. Platt, O. S., S. H. Orkin, G. Dover, G. P. Beardsley, B. Miller, and D. G. Nathan. 1984. Hydroxyurea enhances fetal hemoglobin production in sickle cell anemia. J. Clin. Invest. 74:652-656.

25. Masuda, H., M. Yamamoto, K. Inoluchi, and H. Endo. 1982. Hydroxyurea inhibits degradation of internalized epidermal growth factor in HeLa cells. Biochem. Biophys. Res. Commun. 109:202-209.

26. Earp, S. 1984. Epidermal growth factor receptor-yet another domain? Nature (Lond.). 309:209-210.

27. Hong, S., R. Polsky-Cynkin, and L. Levine. 1979. Stimulation of prostaglandin biosynthesis by vasoactive substance in methylcholanthrene-transformed mouse balb/3T3. J. Biol. Chem. 251:776-780.

28. Stern, P. H., N. S. Krieger, R. A. Nissenson, and R. D. Williams. 1985. Human transforming growth factor-alpha stimulates bone resorption in vitro. J. Clin. Invest. 76:2016-2019.

29. Ibbotson, K. J., D. R. Twardzik, S. M. D’Souza, W. R. Hargreaves,
G. J. Todaro, and G. R. Mundy. 1985. Stimulation of bone resorption in vitro by synthetic transforming growth factor-alpha. Science (Wash. DC). 228:1007-1009.

30. Tashjian, A. H., Jr., E. F. Voelkel, M. Lazzaro, F. R. Singer, A. B. Roberts, R. Derynck, M. E. Winkler, and L. Levine. 1985. Alpha and beta human transforming growth factors stimulate prostaglandin production and bone resorption in cultured mouse calvaria. Proc. Natl. Acad. Sci. USA. 82:4535-4538.

31. Ibbotson, K. J., S. M. D'Souza, K. W. Ng, C. K. Osborne, M. Niall, T. J. Martin, and G. R. Mundy. 1983. Tumor-derived growth factor increases bone resorption in a tumor associated with humoral hypercalcemia of malignancy. Science (Wash. DC). 221:1292-1294.

32. Ibbotson, K. J., S. M. D'Souza, D. D. Smith, G. Carpenter, and G. R. Mundy. 1984. EGF receptor antiserum inhibits bone resorbing activity produced by rat leydig cell tumor associated with the humoral hypercalcemia of malignancy. Endocrinology. 116:469-470.

33. Marquardt, H., M. W. Hunkapiller, L. E. Hood, D. R. Twardzik, J. E. DeLarco, J. R. Stephenson, and G. J. Todaro. 1983. Transforming growth factors produced by retrovirus-transformed rodent fibroblasts and human melanoma cells: amino acid sequence homology with epidermal growth factor. Proc. Natl. Acad. Sci. USA. 80:4684-4688.

34. Mundy, G. R., K. J. Ibbotson, and S. M. D'Souza. 1985. Tumor products and the hypercalcemia of malignancy. J. Clin. Invest. 76:391394. 